\title{
The Implementation of Green Marketing Tools in Rural Tourism: The Readiness of Tourists?
}

\author{
Chee-Hua Chin , Chee-Ling Chin \& Winnie Poh-Ming Wong
}

To cite this article: Chee-Hua Chin , Chee-Ling Chin \& Winnie Poh-Ming Wong (2017): The Implementation of Green Marketing Tools in Rural Tourism: The Readiness of Tourists?, Journal of Hospitality Marketing \& Management, DOI: $10.1080 / 19368623.2017 .1359723$

To link to this article: http://dx.doi.org/10.1080/19368623.2017.1359723

\section{The Implementation of Green Marketing Tools in Rural Tourism: The Readiness of Tourists?}

\author{
Chee-Hua Chin ${ }^{a}$, Chee-Ling China, and Winnie Poh-Ming Wong ${ }^{b}$ \\ aFaculty of Economics and Business, Universiti Malaysia Sarawak (UNIMAS), Kuching, Sarawak, Malaysia; \\ bSchool of Business and Management, University College of Technology Sarawak, Sibu, Sarawak, Malaysia
}

\begin{abstract}
Environmental sustainability is the key factor for the future development of the tourism industry, particularly in sensitive rural tourism destinations. Green tourism and green marketing are alternative practices that ensure the environmental sustainability of tourism destinations. However, green marketing has received little attention in the context of rural destinations. This is the first known study undertaken with the purpose of understanding the relationship between green marketing tools (eco-brand, eco-label, and environmental advertisement) and green purchasing behavior in rural tourism destinations from the perception of tourists. A sample of 252 respondents was selected to complete the questionnaires. To assess the developed model, SmartPLS (version 3.2.6) was applied based on path modeling, followed by bootstrapping. The results revealed that the three-dimensional constructs of green marketing tools were significantly and positively correlated with green purchasing behavior of rural tourism destinations from tourists' perspectives. Several implications, limitations, and directions for future research were further discussed.

环境可持续性是旅游业未来发展的关键因素, 特别是在敏感的乡村 旅游目的地。绿色旅游和绿色营销是确保旅游目的地环境可持续性 的替代性实践。然而, 绿色营销在农村地区却很少受到关注。这是 第一次从游客感知的角度来了解绿色营销工具 (生态品牌、生态标 签和环境广告) 与乡村旅游目的地的绿色购买行为之间的关系。选 取252名被调查者作为样本, 完成问卷调查。评估模型, SmartPLS （版本3.2.6）应用基于路径建模, 其次是引导。研究结果表明, 绿 色营销工具的三维结构与游客视角下乡村旅游地的绿色购买行为呈 显著正相关。进一步讨论了几个含义、局限性和今后研究的方向。
\end{abstract}

\section{KEYWORDS}

Green marketing tools; green purchasing behavior; Malaysia; rural tourism; Theory of Planned Behavior; tourists' perspectives

\section{Introduction}

The tourism industry plays an imperative role as an economic contributor to most countries (Ramjit, 2015; Rosli, 2016). Among more rural communities, there is a growing trend of interest in engaging into rural tourism activities as an alternative source of income generation due to the decline of traditional agricultural sectors (Cai, Liu, \& Huang, 2008; Hoang, 2015). Due to the lucrative income generated from tourism

CONTACT Chee-Hua Chin $\mathbf{c c h}$. febunimas@hotmail.my 0 FEB-PG Room, Level LG, Faculty of Economics and Business, Universiti Malaysia Sarawak (UNIMAS), 94300 Kota Samarahan, Sarawak, Malaysia. 